\title{
Economic Dependency and Opportunity Cost of Childbearing: Implications for fertility control in sub-Sahara Africa
}

OLUWAGBEMIGA ADEYEMI ( $\square$ oluwagbemiga.adeyemi@fuoye.edu.ng )

FEDERAL UNIVERSITY https://orcid.org/0000-0001-8083-8425

Olaide Aderonke Adedokun

Lagos State University

Bolajoko Florence Adeniyi

Federal University Oye-Ekiti

Kolawole Samuel Olowe

Administrative Staff College of Nigeria

Research article

Keywords:

Posted Date: May 20th, 2020

DOl: https://doi.org/10.21203/rs.3.rs-28948/v1

License: () (1) This work is licensed under a Creative Commons Attribution 4.0 International License. Read Full License 


\section{Abstract}

The dynamics in the household income within the marital unions especially with the emergence of female breadwinners in the last decade is gradually changing the demand for children and the need for child spacing. It is in line with this that this study examines the impact of changing spousal roles on the cost of bearing children in three sub-Saharan African countries. Demographic and Health Surveys data were analyzed using three levels of statistical analysis, while at multivariate level, five models were constructed to test the formulated hypotheses. The study identified significant relationship between economic dependency and the control variables (use of modern contraceptives and fertility timing) in the three countries (Pvalue<.0001). The study also affirmed a positive significant relationship between economic dependency and labour force participation of women except in Lesotho (Pvalue <.0001). In addition, higher significant differential was ascertained between labour force participation and fertility in the study area. The three countries also indicate high significant correlation of the effect of women economic dependency on fertility. The study concludes that empowering women and allowing them to involve in paid activities will not only reduce fertility but significantly contribute to poverty reduction in Africa.

\section{Introduction}

Traditionally in Africa, men are regarded as the main income providers for the family. The patriarchal nature of the African society also accrues powers and authority to men with regards to household decision-making. However, the impact of recent economic recession in most African countries and continued dispersal of gender egalitarianism have weakened the dominance of men as breadwinners for their families. This has increased women's participation in productive and paid activities. Vitali \& Arpino (2016) explained that the rise in female-breadwinning role was as a result of the growing phenomenon of gender equality, in addition to economic and institutional challenges which have affected men's employment and earnings. Women are increasingly engaged in paid work as a result of economic necessity. The increase in women participation in the labour force has also reshaped cultural beliefs, reduced gender differences in parenting experiences and promoted understanding of family life between husband and wife. Men have started to see their wives as partners and contributors to the well-being of the family. Available literature also reveal that greater investment in women's education alongside the economic recession which has led to significant job loss among men have placed women in better positions to contribute to the financial well being of the family (Chesley 2011 , Van Bavel, 2012).

While, the inverse relationship between women's labour force participation and fertility has been established in many studies around the world (Adeyemi, Odusina \& Akintoye 2016; Arpino, Esping-Andersen, \& Pessin, 2015, Tortarolo, 2014; Agüero, \& Marks, 2011; Bloom, Canning, Fink \& Finlay, 2009; Billari, \& Ortega 2006), the dual role played by women as breadwinners and home makers has also been found to significantly contribute to lower fertility as women may decide either to delay births or prolong cohabitation without childbearing while young women will delay age at marriage or find alternatives to family building (Brinton and Lee, 2016). Studies in the United States among college students have revealed that easy access to contraceptives affects the timing of marriage, births and incidence of cohabitation. Women will be able to work for pay, invest in on-the-job training and pursue their professional career (Goldin and Katz 2002; Bailey 2006; Guldi 2008; Christensen 2011). The economic theory of women's fertility and work envisages that the competing demands for women's time to work outside the home or to bear and care for children reach equilibrium where the household obtains maximal gain. While human capital theory explained that health and labor force participation are positively correlated, studies have also shown that challenges in individual health will reduce labour force participation, lower productivity and add extra burden to the family income. On the other hand, low productivity as a result of poor health will reduce earning potentials (Zamo-Akono, 2009; Nanfosso \& Zamo-Akono, 2010; Cai and Kalb, 2006; Waghorn and Lloyd, 2005).

In addition, studies have confirmed that higher fertility associated with lower participation in the labour force among women during their reproductive life time, while access to family planning and reduction in birth increase the female labour participation (Bloom et al, 2009, Shareen, 2012). An Indonesian study attests to the likelihood of women participation in the labour force increasing by $20 \%$ with the reduction of one birth over the period of 20 years. Women labour participation and increased level of education increase the value of their time, making it more expensive to bear children (Lam and Duryea, 1999).

Although, studies have examined the changes in the household income provider role (breadwinners' families) with regards to economic recession and social change (Cherlin, 2016; Cory \& Stirling, 2015; Bertrand, Kamenica \& Pan, 2015; Cho \& Newhouse, 2012; Chesley 2011; Cha \& Thébaud, 2009), women's participation in labour force and fertility (Busso \& Fonseca, 2015, Bloom, Canning, Fink \& Finlay, 2009), there are still limited studies on the changing gender roles and its association with fertility choices especially in Sub-Saharan Africa (subsequently SSA). It is thus imperative to answer these questions: how do changes economic dependency affect use of modern contraceptives and timing of next birth? Do changing economic dependency influence opportunity cost of childbearing among married women in SSA? How related are economic dependency, opportunity cost of childbearing and fertility in SSA? Providing answers to these questions will unravel the contextual factors that explain the impact of changing roles on the cost of bearing children in sub-Sahara Africa. The findings will serve as a template for policy makers on how to reduce the fertility level in Africa.

\section{CHANGING ROLES AND FERTILITY IN SUB- SAHARAN AFRICA}

In pre-colonial traditional African societies, the roles of men and women are complementary. Women had opportunity to participate in most activities, although this varies from one society to the other. It was during colonial period that the idea that women belong to the home for childbearing and food preparation was introduced through Western patriarchal structures. This led to the erosion of traditional social institutions and restricted women into disadvantaged vulnerable positions. In many contemporary societies, gender determines the roles played and the relative power wielded by men and women. It also establishes the opportunities and privileges held. It is this patriarchal ideology which exaggerates biological differences between men and women. This becomes even more obvious when one considers that the family remains the social and symbolic place in which sexual differences is believed to be primary and at the same time constructed. Maakama (2013) is of the opinion that patriarchy is a set of social relations that enables men to dominate women. The social relations are also determined by power attributes which influence how society describes what is masculine or feminine. Although '[p]ower is relational, it becomes apparent 
when it is exercised, power is not associated with a particular institution, but with practices, techniques, and procedures, employed at all levels and through many dimensions' (Luna, Gemma \& Dorothea 2017) The value which either men or women hold is tied to their traditional gender-assigned powers which vary from one society to another. For example, in most African rural societies, women are engaged primarily in farming, weaving, pottery, dyeing and trading, while still tied to the home, taking care of the children and playing a subservient role. The role of men which is clearly defined involves providing for the family, and because they occupy the position of head of the family, they make all major decisions including reproductive choices. This creates a division of labour along gender lines and normal family life has come to be defined in terms of a breadwinning husband and a domestic wife with ideal feminine attributes which include sexual innocence and motherhood with the expectation that the woman becomes a hard working household provider.

Some studies have revealed that culturally, women in south-western Nigeria are significantly empowered at the family level, even in responsibilities that are normatively prescribed for men (Ogunjuyigbe and Adeyemi 2005). This implies some degree of autonomy and power in a marital dyad. The powers are usually exercised in the prescribed periods in which women are expected to abstain from sexual relations with their husbands. Such periods include the period before marriage, during menstruation and postpartum period and also on becoming a grandmother. The existence of these prescribed periods reveals that traditionally women have sexual rights. Bogalech and Mengstu, (2007) also explained that in Ethiopia, traditionally, women have little autonomy on most individual and family or household issues, including the option to choose whether to get modern health services during illness, birth, reproductive health services and others.

However, the ability to take such decisions requires a sense of personal autonomy, which develops in tandem with the knowledge that women can provide for themselves and their children. Since the decisions regarding childbearing in most African settings are mostly made by men, it is generally assumed that African men are less inclined to limit their families than women because they operate in a socio-cultural and economic environment that make high fertility beneficial for both men and women. Ths however places the risks and costs primarily on women. Studies also confirm that one of the reasons for large family size in sub-Saharan Africa was because reproductive decision making was more firmly under the control of men (Caldwell and Caldwell 1990, Olusanya 1989). Despite this, changes in the level of education of women, urbanization, industrialization and economic recession have redefined the roles of women in the family and consequently affected family size. Lerch (2013) explained that sharp decline in fertility during the post-socialist transition in Europe and the former Soviet Union was initiated by the adverse material and social consequences of the economic crisis. This has however had a long lasting effect because the onset of childbearing was further postponed even after the economic and political situation stabilized. Studies on women empowerment and fertility in Africa have shown inverse relationship between women empowerment (regarding financial autonomy, household decision making especially reproductive health issues) and fertility (Hindin 2000; Shapiro 2008). Folarinmi (2013) also identified that women who have financial autonomy are more likely to make positive investments in their children thereby increasing their chances of survival during infancy and increasing their likelihood of ever attending school.

\section{Methods}

The study used quantitative data, Demographic and Health Surveys data were used for the analysis with the permission from Measures DHS USA. The data sets for women within 15-49 years were downloaded for three countries in sub-Sahara Africa (Congo 2011, Lesotho 2014, and Nigeria 2013). Each of the countries represent regions in sub-Saharan Africa and their selection was based on the use of modern contraceptive methods among married women. The data were weighted for national representation. More specifically, data for married women and those living with their partners were extracted from women's data and merged together.

\section{Variables}

\section{Outcome Variables}

The outcome variables for this study are opportunity cost of childbearing and fertility. The opportunity cost of bearing children in this study is the alternative forgone which was measured by labour force participation (whom the respondent worked for). These two variables were used as dependent variables. Labour force participation 'whom the respondent worked for' was categorized into 'work for someone else/' $=1$, 'family member/self- Employed' $=0$, while fertility was measured by total children ever born (CEB) which is a count data.

\section{Control Variables}

Studies have established the relationship between birth postponement (use modern contraceptives and fertility timing) and fertility (Casique, 2001, d'Albis, Greulich \& Ponthière 2017). These two variables were used as control variables in the study. Each of these variables was re-categorized into dichotomous variables. 'Currently using modern contraceptives' was dichotomized into 'use modern contraceptives' $=1$ \& 'non-use of modern contraceptives' $=0$. 'Preferred waiting time for birth of a/another child' was used for timing of next birth (birth spacing). This was also dichotomized into $\leq 2 y e a r s=0$ and $>2$ years $=1$

\section{Independent Variable}

The independent variable was economic dependency which was measured by whether the respondent earned more than the husband/partner or equal and partners/husband earn more than the respondents. This was re-categorized into three; respondent earn more (full autonomy =1), Both are equal (Partial=2) and husband/partner earn more (None=3) this classification was based on previous studies on breadwinners (Rogers \& DeBoers 2001, Drago, Black \& Wooden 2004). 


\section{Background variables}

The background variables identified were level of education of respondents, age, place of residence, age at first marriage, wealth index, age at first sexual intercourse and partner's level of education

\section{Data Analysis}

The data for the study were analyzed using three levels of analysis: univariate to show the frequency distributions of the socio-demographic characteristics of the respondents; proximate variables and explanatory variables. The Bivariate analysis was used to show the differentials in the economic dependency among women and some selected variables. For multivariate analysis, two statistical techniques were used and five models were constructed to test the formulated hypotheses. Model 1 shows the unadjusted relationship between economic dependency and opportunity cost while model 2 pointed out the effect of the contol variables on economic dependency and opportunity cost of childbearing. Model 3 reveals the relative risk of economic dependency, opportunity cost of childbearing and fertility, Model 4 established the relationship between the independent variables, control variables and fertility while model 5 is the complete model including background variables. Binary logistic regression was used to show the relationship between outcome variables (opportunity cost of childbearing) and independent variable (economic dependency). While Poisson regression was used to estimate the incidence of relative risk (IRR) of economic dependency and opportunity cost of bearing children on fertility (total children ever born) which is a count data (see Table 1). 
Variables used in the models

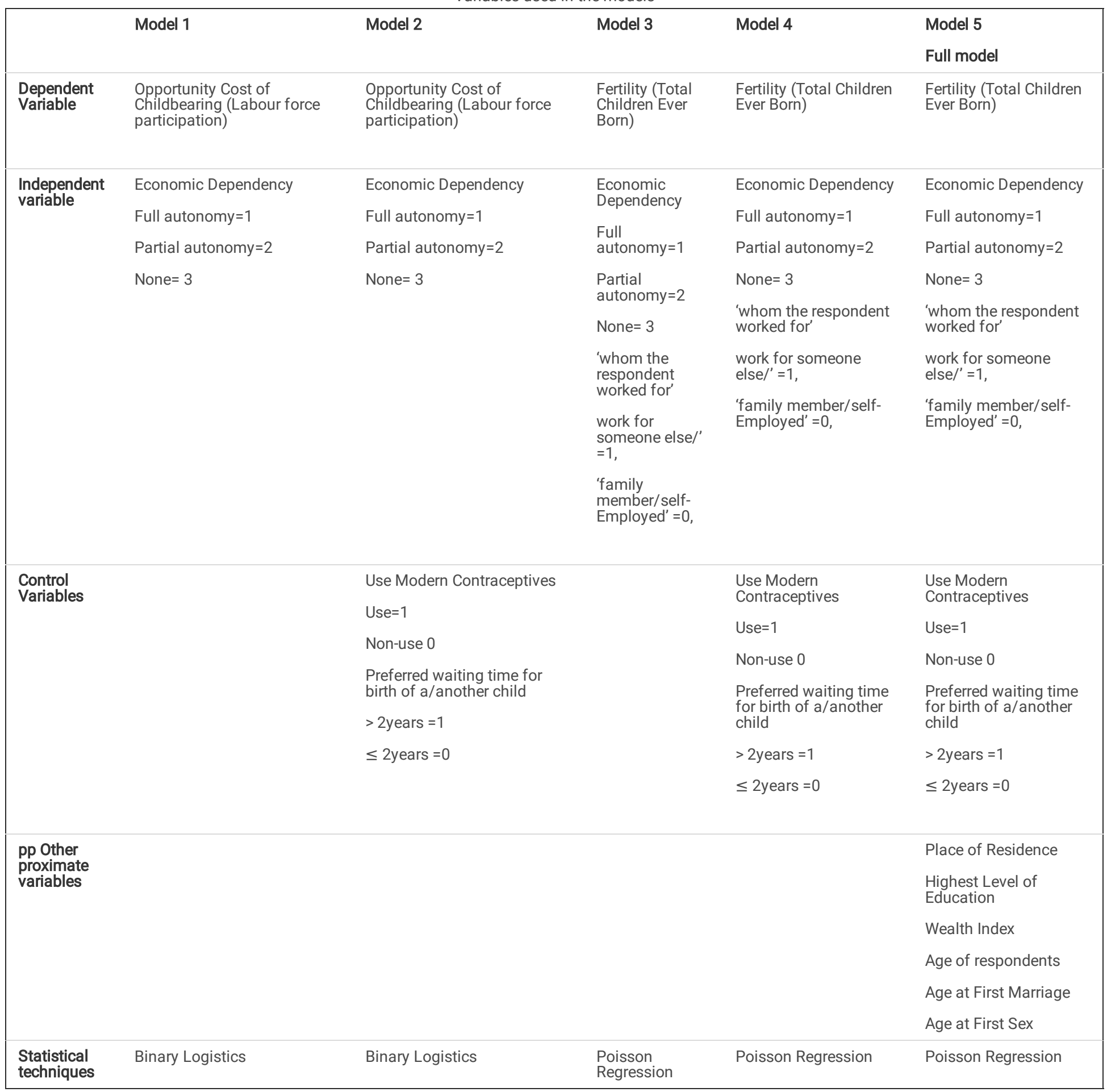

\section{Results}

The study established from Table 1 that majority of the married women were from rural areas except in Congo Brazzaville, while with the pooled data, (38.9\%) of the sampled population lived in urban centres. In all the counties except in Lesotho more than half majority of the respondents had secondary education while Nigeria has the highest women with higher education (6.4\%) followed by Lesotho. With respect to wealth index, Congo Brazzaville had the highest women at the poor layer of the wealth index (38.7\%) followed by Lesotho $(23 \%)$ while with the pooled data, two out of every five women sampled in the study are poor. It is also important to note that Lesotho has the highest percentage of richest women ( $48.1 \%$ followed by Nigeria (38.2\%). In relation to the age of the respondents, Nigeria has the highest number of women between age $25-34$ years (44.6\%) followed by Congo Brazzaville (41.3\%). In the pooled data, $38 \%$ of the women are between ages 15 and 24 years. In all the three countries, more than half of the women married between age 16-20 years while Nigeria has the highest number of women that married at older age 26 years and above (13.2\%). It was also revealed that Nigeria has the highest number of women who had given birth to 4 and above children while Lesotho has highest number of women with no children. 
Table 2

Percentage distribution of selected socio-demographic variables

\begin{tabular}{|c|c|c|c|c|}
\hline & CONGO & LESOTHO & NIGERIA & POOL DATA \\
\hline \multicolumn{5}{|l|}{ VARIABLES } \\
\hline \multicolumn{5}{|c|}{ Place of Residence } \\
\hline Urban & 64.1 & 31.8 & 49.2 & 48.8 \\
\hline Rural & 35.9 & 68.2 & 50.8 & 51.2 \\
\hline Total & 100 & 100 & 100 & 100 \\
\hline \multicolumn{5}{|c|}{ Highest Level of Education } \\
\hline No Education & 7.2 & 1.3 & 8.0 & 5.4 \\
\hline Primary & 26.7 & 44.4 & 23.3 & 31.8 \\
\hline Secondary & 61.7 & 46.1 & 62.3 & 56.8 \\
\hline Higher & 4.5 & 6.3 & 6.4 & 5.9 \\
\hline Total & 100 & 100 & 100 & 100 \\
\hline \multicolumn{5}{|l|}{ Wealth Index } \\
\hline Poor & 38.7 & 19.0 & 11.5 & 33.2 \\
\hline Middle & 20.3 & 6.3 & 19.6 & 19.7 \\
\hline Richer & 21.4 & 26.6 & 32.7 & 23.6 \\
\hline Richest & 19.6 & 48.1 & 38.2 & 23.6 \\
\hline Total & 100 & 100 & 100 & 100 \\
\hline \multicolumn{5}{|l|}{ Age-group } \\
\hline $15-24$ & 23.8 & 26.5 & 34.3 & 26.1 \\
\hline $25-34$ & 41.3 & 39.5 & 44.6 & 41.1 \\
\hline $35-44$ & 26.8 & 25.5 & 16.6 & 24.9 \\
\hline $45+$ & 8.1 & 8.6 & 4.5 & 7.8 \\
\hline Total & 100 & 100 & 100 & 100 \\
\hline \multicolumn{5}{|c|}{ Age at First Marriage } \\
\hline$<15$ years & 20.4 & 7.8 & 13.9 & 33.4 \\
\hline $16-20$ & 50.4 & 60.7 & 65.1 & 50.8 \\
\hline $21-25$ & 21.2 & 23.4 & 27.8 & 5.3 \\
\hline $26+$ & 8.0 & 8.1 & 13.2 & 10.5 \\
\hline Total & 100 & 100 & 100 & 100 \\
\hline \multicolumn{5}{|c|}{ TOTAL CHILDREN EVER BORN } \\
\hline 0 & 5.8 & 9.0 & 15.1 & 7.8 \\
\hline $1-3$ & 54.8 & 50.2 & 58.1 & 60.2 \\
\hline $4-6$ & 30.5 & 28.1 & 20.5 & 25.2 \\
\hline $7+$ & 9.0 & 12.7 & 6.3 & 6.8 \\
\hline Total & 100 & 100 & 100 & 100 \\
\hline
\end{tabular}

The bivariate analysis between economic dependency and birth postponement in Table 3 shows that women with full financial autonomy have the highest percentage among women who used contraceptives in all the countries including the pooled data. The significant relationship between economic dependency and use of modern contraceptives was established in the study $\left(X_{3}^{2}\right.$ Pvalue $\left.=.000\right)$. It was also noted that more than two-thirds of women with full financial autonomy indicated preference to have their next birth after two years. Significant relationship between economic dependency and fertility time was reaffirmed in the study $\left(X^{2}\right.$ Pvalue $\left.=.000\right)$ except in Lesotho 
Table 3

Economic Dependency and Birth postponement

\begin{tabular}{|c|c|c|c|c|c|c|c|c|}
\hline & \multicolumn{4}{|c|}{ Use Modem Contraceptives } & \multicolumn{4}{|c|}{ Waiting periods } \\
\hline & Use & Non-use & Total & $\mathrm{X}^{2}$ Pvalue & $<2$ years & $>2$ years & Total & $\mathrm{X}^{2}$ Pvalue \\
\hline \multicolumn{9}{|l|}{ Congo } \\
\hline Full Autonomy & 29.5 & 70.5 & 100 & \multirow[t]{3}{*}{.000} & 19.5 & 80.5 & 100 & \multirow[t]{3}{*}{.000} \\
\hline Partial Autonomy & 24.1 & 75.9 & 100 & & 25.8 & 74.2 & 100 & \\
\hline None & 23.7 & 76.5 & 100 & & 30.5 & 69.5 & 100 & \\
\hline \multicolumn{9}{|l|}{ Lesotho } \\
\hline Full Autonomy & 60.2 & 39.8 & 100 & \multirow[t]{3}{*}{.000} & 38.8 & 61.2 & 100 & \multirow[t]{3}{*}{.353} \\
\hline Partial Autonomy & 57.5 & 42.5 & 100 & & 37.9 & 62.1 & 100 & \\
\hline None & 47.8 & 52.2 & 100 & & 44.9 & 55.1 & 100 & \\
\hline \multicolumn{9}{|l|}{ Nigeria } \\
\hline Full Autonomy & 33.1 & 66.9 & 100 & \multirow[t]{3}{*}{.000} & 10.0 & 90.0 & 100 & \multirow[t]{3}{*}{.000} \\
\hline Partial Autonomy & 21.1 & 78.9 & 100 & & 46.7 & 53.3 & 100 & \\
\hline None & 21.6 & 78.4 & 100 & & 44.0 & 56.0 & .100 & \\
\hline \multicolumn{9}{|l|}{ Pooled Data } \\
\hline Full Autonomy & 57.9 & 42.1 & 100 & \multirow[t]{3}{*}{.000} & 37.1 & 62.9 & 100 & \multirow[t]{3}{*}{.000} \\
\hline Partial Autonomy & 34.9 & 65.1 & 100 & & 30.8 & 69.2 & 100 & \\
\hline None & 31.8 & 68.2 & 100 & & 45.0 & 65.0 & 100. & \\
\hline
\end{tabular}

In Table 4, Model 1 pointed out the relationship between economic dependency and opportunity cost of childbearing with logistic regression. Significant relationship was ascertained between women who have full autonomy and opportunity cost of childbearing in all the countries including the pooled data except Congo ( Lesotho Odd Ratio $=.743$ Pvalue $<.005$, Nigeria Odd Ratio $=.092$ Pvalue $<.001$, Pooled data Odd Ratio $=4.128$ Pvalue $<.001$ ) while significant relationship was established with women with partial autonomy and use of modern contraceptives in all the countries except Lesotho ( Congo Odd Ratio $=.286$ Pvalue $<.005$, Nigeria Odd Ratio $=.424$ Pvalue $<.001$, Pooled data Odd Ratio $=.714$ Pvalue $<.001$.) When the model was control as indicated in model 2 , women with full autonomy was only significant in Lesotho and pooled data (( Lesotho Odd Ratio $=. .546$ Pvalue $<.005$, Pooled data Odd Ratio Pvalue $<.001)$, while it was only significant with partial autonomy in Nigeria and pooled data. The significant relationship between fertility timing and opportunity cost of childbearing was identified in all the counties including the pooled data 
Table 4

LOGISTIC REGRESSION OF ECONOMIC DEPENDENCY AND OPPORTUNITY COST OF CHILDBEARING

\begin{tabular}{|c|c|c|c|c|c|c|c|c|c|c|c|c|c|}
\hline \multirow{3}{*}{$\begin{array}{l}\text { VARIABLES } \\
\text { Economic } \\
\text { Dependency }\end{array}$} & \multicolumn{8}{|c|}{ Model 1} & \multicolumn{5}{|l|}{ Model 2} \\
\hline & \multicolumn{2}{|c|}{ CONGO } & \multicolumn{2}{|c|}{ LESOTHO } & \multicolumn{2}{|c|}{ NIGERIA } & \multicolumn{2}{|c|}{ POOLED DATA } & \multicolumn{2}{|l|}{ CONGO } & \multicolumn{2}{|c|}{ LESOTHO } & \multirow{2}{*}{$\begin{array}{l}\text { NIGER } \\
\text { Exp } \\
(\beta)\end{array}$} \\
\hline & $\begin{array}{l}\operatorname{Exp} \\
(\beta)\end{array}$ & $\mathrm{Cl}$ & $\begin{array}{l}\operatorname{Exp} \\
(\beta)\end{array}$ & $\mathrm{Cl}$ & $\begin{array}{l}\text { Exp } \\
(\beta)\end{array}$ & $\mathrm{Cl}$ & $\operatorname{Exp}(\beta)$ & $\mathrm{Cl}$ & $\operatorname{Exp}(\beta)$ & $\mathrm{Cl}$ & $\operatorname{Exp}(\beta)$ & $\mathrm{Cl}$ & \\
\hline Full Autonomy & .000 & $.000-.728$ & $.743^{\star}$ & $\begin{array}{l}.549- \\
1.006\end{array}$ & $.092 * *$ & $.092-.093$ & 4.128 ** & $\begin{array}{l}4.126- \\
4.128\end{array}$ & .000 & $.000-294$ & $.546^{*}$ & $\begin{array}{l}.537- \\
2.197\end{array}$ & .439 \\
\hline $\begin{array}{l}\text { Partial } \\
\text { Autonomy }\end{array}$ & $.286^{\star}$ & $.285-.286$ & .553 & $\begin{array}{l}.553- \\
1.253\end{array}$ & $.424^{\star \star}$ & $.424-.425$ & $.714^{\star \star}$ & $\begin{array}{l}.741- \\
715\end{array}$ & .282 & $.282-.282$ & 1.086 & $\begin{array}{l}.537- \\
2.137\end{array}$ & $.240^{\star \star}$ \\
\hline None & $\mathrm{RC}$ & 1.00 & $\mathrm{RC}$ & 1.00 & $\mathrm{RC}$ & 1.00 & $\mathrm{RC}$ & 1.00 & $\mathrm{RC}$ & 1.00 & $\mathrm{RC}$ & 1.00 & $\mathrm{RC}$ \\
\hline \multicolumn{14}{|l|}{ Use Modern } \\
\hline \multicolumn{14}{|l|}{ Contraceptives } \\
\hline Use & - & - & - & - & - & - & - & - & $\mathrm{RC}$ & 1.00 & $\mathrm{RC}$ & 1.00 & $\mathrm{RC}$ \\
\hline Non-Use & - & - & - & - & - & - & - & - & $.526 * \star$ & $.526-.526$ & $2.896^{\star \star}$ & $\begin{array}{l}1.922- \\
4.272\end{array}$ & $.238 * x$ \\
\hline \multicolumn{14}{|l|}{ Waiting Period } \\
\hline$>2$ years & - & - & - & - & - & - & - & - & $\mathrm{RC}$ & 1.00 & $\mathrm{RC}$ & 1.00 & $\mathrm{RC}$ \\
\hline$\leq 2$ years & - & - & - & - & - & - & - & - & 2.120 ** & $\begin{array}{l}2.121- \\
2.122\end{array}$ & $.620 * \star$ & $.412-.932$ & $.361^{\star *}$ \\
\hline
\end{tabular}

Model 3 in Table 5 shows the Poison regression of economic dependency, opportunity cost and total children ever born in the study area. A significant effect of economic dependency (full autonomy and partial autonomy) on children ever born was reaffirmed for all the three countries including the pooled data ( $\mathrm{P}$ $<.001)$, while a significant higher effects of the opportunity cost of childbearing was retreated in the study $(P<.001)$ When the data was adjusted with confound variables in model 4, significant higher effects was confirmed with economic dependency (full autonomy and partial autonomy) except for pooled data ( Partial autonomy Congo Brazzaville Odd Ratio = 1.141, P value .000; Partial autonomy Lesotho Odd Ratio =-1.12, P value .000; Partial autonomy Nigeria Odd Ratio $=-1.242$, P value .000 , Partial autonomy pooled data $.855 \mathrm{P}$ value .000 ). For opportunity cost of childbearing, a significant coefficient was found with children ever born in all the countries including the pooled data $(P<.001)$. With the full model in Table 6 , a significant effect of economic dependency (full autonomy and partial autonomy) was ascertained in all the countries except in Lesotho while opportunity cost for childbearing remains significant with children ever born in all the countries 
POISSON REGRESSION OF ECONOMIC DEPENDNECY, OPPORTUNITY COST OF CHILDBEARING AND FERTILITY

\begin{tabular}{|c|c|c|c|c|c|c|c|c|c|c|c|c|c|}
\hline \multirow[b]{3}{*}{$\begin{array}{l}\text { Economic } \\
\text { Dependency }\end{array}$} & \multicolumn{8}{|l|}{ Model 3} & \multicolumn{5}{|l|}{ Model 4} \\
\hline & \multicolumn{2}{|l|}{ CONGO } & \multicolumn{2}{|c|}{ LESOTHO } & \multicolumn{2}{|l|}{ NIGERIA } & \multicolumn{2}{|c|}{ POOLED DATA } & \multicolumn{2}{|l|}{ CONGO } & \multicolumn{2}{|c|}{ LESOTHO } & \multirow{2}{*}{$\begin{array}{l}\mathrm{Nl} \\
\mathrm{E}>\end{array}$} \\
\hline & $\operatorname{Exp}(\beta)$ & $\mathrm{Cl}$ & $\begin{array}{l}\operatorname{Exp} \\
(\beta)\end{array}$ & $\mathrm{Cl}$ & $\operatorname{Exp}(\beta)$ & $\mathrm{Cl}$ & $\operatorname{Exp}(\beta)$ & $\mathrm{Cl}$ & $\operatorname{Exp}(\beta)$ & $\mathrm{Cl}$ & $\operatorname{Exp}(\beta)$ & $\mathrm{Cl}$ & \\
\hline Full Autonomy & $.988^{* *}$ & $.988-.989$ & $.742^{\star \star}$ & $.701-.784$ & $.717 \star \star$ & $.717-.717$ & $.793^{\star \star}$ & $.793-.793$ & 1.187 ** & $\begin{array}{l}1.186- \\
1.187\end{array}$ & $.896^{\star *}$ & $\begin{array}{l}.741- \\
1.084\end{array}$ & 1. \\
\hline $\begin{array}{l}\text { Partial } \\
\text { Autonomy }\end{array}$ & $1.69 * \star$ & $\begin{array}{l}1.69- \\
1.69\end{array}$ & .980 & $\begin{array}{l}.950- \\
1.012\end{array}$ & $.851^{\star \star}$ & $.851-.851$ & $1.011^{\star *}$ & $\begin{array}{l}1.011 \\
-1.011\end{array}$ & $1.141^{\star \star}$ & $\begin{array}{l}1.41- \\
1.42\end{array}$ & $1.112^{\star \star}$ & $\begin{array}{l}.983- \\
1.422\end{array}$ & 1. \\
\hline None & $\mathrm{RC}$ & 1.000 & $\mathrm{RC}$ & 1.000 & $\mathrm{RC}$ & 1.000 & $\mathrm{RC}$ & 1.000 & $\mathrm{RC}$ & 1.00 & $\mathrm{RC}$ & 1.00 & $\mathrm{Rl}$ \\
\hline $\begin{array}{l}\text { Use Modern } \\
\text { Contraceptives }\end{array}$ & - & - & - & - & - & - & - & - & & & & & \\
\hline Use & - & - & - & - & - & - & - & - & $\mathrm{RC}$ & 1.00 & $\mathrm{RC}$ & 1.00 & $\mathrm{Rl}$ \\
\hline Non-use & - & - & - & - & - & - & - & - & $1.048^{\star *}$ & $\begin{array}{l}1.048- \\
1.048\end{array}$ & $1.097^{\star \star}$ & $\begin{array}{l}.971- \\
1.239\end{array}$ & .9 \\
\hline Waiting Period & - & - & - & - & - & - & - & - & & & & & \\
\hline$>2$ years & - & - & - & - & - & - & - & - & $\mathrm{RC}$ & 1.00 & $\mathrm{RC}$ & 1.00 & $\mathrm{Rl}$ \\
\hline$\leq 2$ years & - & - & - & - & - & - & - & - & $1.156^{\star \star}$ & $\begin{array}{l}1.156- \\
1.156\end{array}$ & $.886^{\star *}$ & $\begin{array}{l}787- \\
996\end{array}$ & .8 \\
\hline \multicolumn{14}{|l|}{$\begin{array}{l}\text { Whom she } \\
\text { Worked for }\end{array}$} \\
\hline Someone else & $\mathrm{RC}$ & 1.000 & $\mathrm{RC}$ & 1.000 & $\mathrm{RC}$ & 1.000 & $\mathrm{RC}$ & 1.000 & $\mathrm{RC}$ & 1.00 & $\mathrm{RC}$ & 1.00 & $\mathrm{R}$ \\
\hline Family/self & $1.243^{* *}$ & $\begin{array}{l}1.213- \\
1,213\end{array}$ & $.946^{\star \star}$ & $.919-.974$ & $1.087^{\star \star}$ & $\begin{array}{l}1.087- \\
1.087\end{array}$ & $.899 * \star$ & $.899-.899$ & $1.156^{\star \star}$ & $\begin{array}{l}1.156- \\
1.156\end{array}$ & $.915^{\star \star}$ & $\begin{array}{l}.783 \\
- \\
1.070\end{array}$ & 1. \\
\hline
\end{tabular}


Table 6

POISSON REGRESSION OF ECONOMIC DEPENDNECY, OPPORTUNITY COST OF CHILDBEARING AND FERTILITY (Full Model)

\begin{tabular}{|c|c|c|c|c|c|c|c|c|}
\hline \multirow[b]{2}{*}{ Economic Dependency } & \multicolumn{2}{|l|}{ CONGO } & \multicolumn{2}{|c|}{ LESOTHO } & \multicolumn{2}{|l|}{ NIGERIA } & \multicolumn{2}{|c|}{ POOLED DATA } \\
\hline & $\operatorname{Exp}(\beta)$ & $\mathrm{Cl}$ & $\operatorname{Exp}(\beta)$ & $\mathrm{Cl}$ & $\operatorname{Exp}(\beta)$ & $\mathrm{Cl}$ & $\operatorname{Exp}(\beta)$ & $\mathrm{Cl}$ \\
\hline Full Autonomy & $1.067^{\star \star}$ & $1.067-1.068$ & .863 & $.709-1.050$ & $.923^{\star \star}$ & $.923-.924$ & $.823^{\star \star}$ & $.823-.823$ \\
\hline Partial Autonomy & $.996 * \star$ & $.966-.966$ & 1.095 & $.909-1.319$ & $.961^{\star \star}$ & $.961-.961$ & $.961^{\star \star}$ & $.961-.961$ \\
\hline None & $\mathrm{RC}$ & 1.00 & $\mathrm{RC}$ & 1.00 & $\mathrm{RC}$ & 1.00 & $\mathrm{RC}$ & 1.00 \\
\hline \multicolumn{9}{|l|}{ Use Modern } \\
\hline \multicolumn{9}{|l|}{ Contraceptives } \\
\hline Use & $\mathrm{RC}$ & 1.00 & $\mathrm{RC}$ & 1.00 & $\mathrm{RC}$ & 1.00 & $\mathrm{RC}$ & 1.00 \\
\hline Non-use & $.874^{\star \star}$ & $.874-.874$ & $1.012^{\star \star}$ & $.893-1.147$ & $.879 * \star$ & $.879-.879$ & $.926^{\star \star}$ & $.926-.926$ \\
\hline \multicolumn{9}{|l|}{ Waiting Period } \\
\hline$>2$ years & $\mathrm{RC}$ & 1.00 & $\mathrm{RC}$ & 1.00 & $\mathrm{RC}$ & 1.00 & $\mathrm{RC}$ & 1.00 \\
\hline$\leq 2$ years & $.577 \star \star$ & $.577-.577$ & $.732^{\star \star}$ & $.646-830$ & $.747 * \star$ & $.746-.747$ & $.803^{\star \star}$ & $.803-803$ \\
\hline \multicolumn{9}{|l|}{ Whom she Worked for } \\
\hline Someone else & $\mathrm{RC}$ & & $\mathrm{RC}$ & & & & & \\
\hline Family/self & $1.024^{\star \star}$ & &. $.844^{\star}$ & $.723-987$ & $1.290 \star \star$ & $1.289-1.290$ & $1.088^{\star \star}$ & $1.085-1.088$ \\
\hline Place of Residence & $1.08^{\star \star}$ & $1.08-1.08$ &. .844 & $.723-987$ & $.917 * *$ & $.917-.917$ & $.963^{\star \star}$ & $.963-.967$ \\
\hline Highest Level of Education & $.903^{\star \star}$ & $.903-.903$ & .960 & $.873-1.055$ & $1.113^{\star \star}$ & $1.113-1.113$ & $.965^{\star \star}$ & $.860-.965$ \\
\hline Wealth Index & $.951^{\star \star}$ & $.951-.951$ & .955 & $.899-1.016$ & $.910 * \star$ & $.910-.910$ & $.969 \star \star$ & $.969-971$ \\
\hline Age-group & 1.377 & $1.377-1.377$ & $1.386^{\star \star}$ & $1.324-1.469$ & $1.424^{\star \star}$ & $1.424-1.424$ & $1.386^{\star \star}$ & $1.325-1.449$ \\
\hline Age at First Marriage & $.822^{\star \star}$ & $.822-.822$ & $.808^{\star \star}$ & $.751-.856$ & $.708^{\star *}$ & $. .768-.769$ & $.768 * \star$ & $.768-.768$ \\
\hline Age at First Sex & $.966^{\star \star}$ & $.966-.966$ & 1.037 & $.974-1.104$ & $1.031^{\star \star}$ & $1.031-1.031$ & $1.031^{\star \star}$ & $1.030-1.031$ \\
\hline
\end{tabular}

\section{Discussion}

The results of the analysis have pointed out the impacts of changing roles (economic dependency) on opportunity cost of bearing children in sub-Sahara Africa. The pattern of education shows that majority of the women had secondary education while Lesotho has the highest women with primary education. This is an indication that there is an improvement in the women's level of education with resultant effect on financial autonomy. The exposure of women to western education enables them to delay marriage, control family preference and become more knowledgeable about modern contraceptives methods. Odusina (2017) explained that education will afford women the opportunity to control the number of children and they will be well informed about the health services including family planning and the implications of large family size on the well-being of the mothers. It is believed that with higher levels of education, women's expectation of future earnings will be higher and this will eventually increase the likelihood of giving births and raising children. However, Hoem, Weye \& Anderson (2006) opine that field of education serves as an indicator of a woman's potential reproductive behaviour better than the simple identification that the women's level of education. While education will improve women participation in the labour force and reduce family size, some studies are of the opinions that the effect of female labour participation on fertility will depend on the type of occupation, especially with consideration for its friendliness with childbearing responsibility (Perticara 2006; Wusu 2012; Adeyemi, Odusina \& Akintoye 2016). Pampel (2011) observed that the increase in the proportion of women with higher education, good-paying jobs and commitment to careers outside home will bring about changes in gender egalitarianism resulting to later marriage and fewer numbers of children. Those who engage in career that take them away from home will find it difficult to combine the responsibility of their job with childbearing which will have impact on the family size.

Despite these however, the age at first marriage of the full financial autonomy indicated that almost two-thirds of the respondents married before age twenty (See Fig. 2). This is reflective of early marriage practices in many sub-Sahara African countries. Adedokun, Adeyemi \& Dauda (2016) identified poverty as the core factor that influences early marriage in low income countries, since they lack resources to support healthy alternatives for girls, such as prolonged schooling and skill acquisition to secure their future. Delaying marriage will increase girls' and women's decision-making power, increase incomes for individuals and advance economic development for nations. A single year of primary school increases women's wages later in life from 10-20\% (Psacharopoulos \& Patrinos 2002; Lloyd. 2005).

The positive significant relationship between economic dependency and use of modern contraceptives in the study area exposes the impact of financial autonomy on fertility. Where women have no control over money, they cannot choose to get health care for themselves or their children. Neither are they able to negotiate when and what type of sex to have, nor to protest their husbands' multiple sex partners. A low status for women will result to short birth intervals and vice versa, as women strive to maximize the number of children they can have within their reproductive lives (Hobcraft, 2000). Women's financial status 
will influence her decision making concerning contraceptive use and family size. Studies in India established that women with greater autonomy have, if not more, equal say as far as the fertility preferences and contraception uses are concerned. In truth, sometimes they are found to dictate the decision regarding family planning use (Kamal 2012). Similar studies using DHS in Africa confirm that female autonomy is an important contextual factor in the use of modern contraceptives among women. They emphasized that women who are working usually have no desire for more children and showed significant higher chances of using modern contraceptives (Rastogi and Nguyen, 2005; Alabi, et al 2019). In the same vein, the positive significant effect of economic dependency on waiting period for another child in the study reaffirmed the link between women's labour force participation and fertility timing. Women who have financial autonomy or control over economic resources within the household will have opportunity to decide when to have the next child and use family planning. Thus, women who are involved in the household decision making are more likely to space their births and use family planning (Malhotra et al 2002). Women financial empowerment will influence reproductive outcomes including contraceptive use, family size and births intervals.

The higher significant effect of labour force participation on fertility in the study was in support of the previous studies (Wusu, 2012, Bloom, Canning et al. 2007) women who work for someone else likely to work in formal sector with tendency of having smaller family size.. Increase in the level of education, modernization and urbanization have made the opportunity cost of women stay at home very high. As the investment in human capital increases there is likelihood of more women in labour market with changes in the fertility behaviour in favour of smaller family size (Lam and Duryea, 1999). It was documented that changes in the household income as a result of unemployment, economic recession and privatization policy will shift the cost of childbearing from society to family thereby resulting in a decline in total children ever born (Eltigani, 2005). All the same, the dual shifts inside and outside the home may also influence women not to have additional children, or delay having another child in order to avoid the additional burdens (Craig and Siminski 2010). Similarly, it is expected that where house chores are shared or men are involved in the housework as a result of the contribution of the wife to family income, the number of children the family intends to have will be affected. Studies from Europe revealed a positive relationship between husband involvement in childcare and the risk of having the second child in Spain and Italy (Cooke 2009).

In all, this study has established significant relationship between economic dependency, opportunity cost of childbearing and fertility in all the three countries under study. Woldemicael (2009) found out that increased participation in household decision making among women was associated with lower fertility and discussion of ideal family size with partners. Those who are engaged in earnings that contributed to the household income will have the confidence to discuss with their partners concerning fertility preference and family size. Socio- and demographic factors such as employment and economic status affect women's reproductive preferences not only positively but also indirectly by increasing their autonomy, independence and reproductive judgment within their household and community. The study has reaffirmed that fertility choices within conjugal unions does not only depend on father's activity but also on the mothers earning status.

\section{Conclusion and Contribution to knowledge}

The study has drawn attention to the effect of economic dependency on the fertility behaviour of women in SSA. The dynamics in the household income within the marital unions especially with the emergence of female breadwinners in the last decade is gradually changing the demand for children and the need for child spacing. This will not only reduce the fertility rate in SSA but will also improve the health of women and reduce maternal mortality in SSA. In fact, one of the cardinal goals of Sustainable Development Goals (SDGs), especially goal 5, is to "achieve gender equality and empower all women and girls".

Empowering women and allowing them to involve in paid activities will not only reduce fertility but significantly contribute to poverty reduction in Africa. It is therefore necessary to educate females up to secondary school level. This will increase their labour force participation and improve their reproductive health status. Government should ensure free education for female up to senior secondary school and checkmate all socio-cultural factors that may lead to girls dropping out of school.

\section{Limitation Of The Study}

This study is limited with some factors which are important to mention. Firstly, the study make used of DHS data which are cross-sectional and the causal relationship cannot be mentioned. Secondly, it is also very difficult to calculate the percentage of income contributed by each partner to maintain the family. Thirdly, the economic situations in those countries may also affect the fertility choices of the respondents which may not reflect the true fertility desired as contained in the survey. Despite the fact that DHS survey used similar survey design and questionnaire, it was also noticed that some variables of labour force participation are not available especially when compared with previous surveys.

\section{Declarations}

\section{Authors Contribution}

1. Analysis and Discussion

2. Introduction

3. Literature Review

4. Methods and Analysis

\section{Competing interests}

No competing interest 


\section{Funding}

No funding

\section{Acknowledgements}

The authors acknowledge MEASURE DHS /USAID for granting us permission to use the data. We also thank Dr. Onunuga for proofreading the manuscript/

\section{References}

1. Adedokun O, Adeyemi O, Dauda C. (2016). Child marriage and maternal health risks among young mothers in Gombi, Adamawa State, Nigeria:implications for mortality, entitlements and freedoms. Afri Health Sci 2016;16(4): 986-999.

2. Adeyemi EO, Odusina EK, Akintoye EA. (2016) Religion and Labour Force Participation in Nigeria: Is there any Inequality among Women? African Journal of Reproductive Health Vol 30 (2) Pg 75-84.

3. Motherhood and female labor supply in the developing Agüero JM, Marks MS. (2011). Motherhood and female labor supply in the developing.

4. world evidence from. infertility shocks. Journal of Human Resources, 46(4), 800-826.

5. Ahn N, Mira P. A note of the relationship between fertility and female employment rates in developed countries. J Popul Econ. 2002;15(4):667-82.

6. Alabi, Olatunji, Odimegwu Clifford O,De-Wet Nicolec\&. Akinyemi Joshua O. (2019) Does Female Autonomy Affect Contraceptive Use among Women in Northern Nigeria ? African Journal of Reproductive Health · 23(2) 92-100.

7. Arpino B, Esping-Andersen G, Pessin L. Changes in gender role attitudes and fertility: A macro-level analysis. Eur Sociol Rev. 2015;31(3):370-82. doi:10.1093/esr/jcv002.

8. Bailey MJ. More Power to the Pill: The Impact of Contraceptive Freedom on Women's Lifecycle Labor Supply. Quart J Econ. 2006;121(1):289-320.

9. Bertrand M, Kamenica E, Pan J. Gender identity and relative income within households. Q J Econ. 2015;130(2):571-614. doi:10.1093/qje/qjv001.

10. Fertility, female labor force

Bloom DE, Canning D, Fink G, Finlay JE. (2009). Fertility, female labor force.

11. participation. and the demographic dividend. Journal of Economic Growth, 14(2), 79 -

12. 101.

13. Brewster, K.L. and Rindfuss, R. (2000). Fertility and women's employment in industrialized nations. Annual Review of Sociology 26: 271-296. doi:10.1146/annurev.soc.26.1.271

14. Busso, M., \& Fonseca, D. R. (2015). Determinants of female labor force participation.

15. Bridging gender gaps, $199-260$.

16. Cai, L. and Kalb, G. (2006), 'Health Status and Labour Force Participation: Evidence from Australia', Health Economics, 15(3): 241-261

17. Casique Irene (2001) What diference does it make? women's autonomy and power and use of contraception in Mexico Paper Presented at the XXIV IUSSP General Population Conference

18. Salvador, Bahia, August 2001

19. Cha, Y. and Thébaud, S. (2009). Labor markets, breadwinning, and beliefs how economic context shapes men's gender ideology. Gender \& Society 23(2): 215- 243. doi:10.1177/0891243208330448

20. . Cherlin, A.J. (2016). A happy ending to a half-century of family change? Population and Development Review 42(1): 121-129. doi:10.1111/j.17284457.2016.0011 1.x.

21. Chesley Noelle (2011) Stay-At-Home Fathers And Breadwinning Mothers: Gender, Couple Dynamics, and Social Change Source: Gender and Society, Vol. 25, No. 5 (October 2011),pp. 642-664Published by: Sage Publications, Inc. Stable URL: ttps://

22. Accessed: 21-06-2019 11:01 UTC

23. Cho, Y. and Newhouse, D. (2012). How did the great recession affect different types of workers? Evidence from 17 middle-income countries. World Development 41: 31-50.doi:10.1016/j.worlddev.2012.06.003. C

24. Cooke, L.P. (2006). 'Doing' gender in context: Household bargaining and risk of divorce in Germany and the United States. American Journal of Sociology 112(2): 442-472. doi:10.1086/506417

25. Cooke, L.P. (2009). Gender equity and fertility in Italy and Spain. Journal of Social Policy 38(1): 123-140. doi:10.1017/S0047279408002584.

26. Cory, G. and Stirling, A. (2015). Who's breadwinning in Europe? A comparative analysis of maternal breadwinning in Great Britain and Germany. London: Institute for Public Policy Research (IPPR). http://www.ippr.org/publications/ whos-breadwinning-in-europe.

27. Craig, L. and Siminski, P. (2010a). If men do more housework, do their wives have more babies? Social Indicators Research 101(2): 255-258. doi:10.1007/s11205-010-9644-1.

28. d'Albis Hippolyte, Greulich Angela \& Ponthière Grégory (2017) Education, labour, and the demographic consequences of birth postponement in Europe Demographic Research 36 (23), pp 691-728 http://www.demographic-research.org/Volumes/Vol36/23/ D0I:10.4054/DemRes.2017.36.23

29. David E. Bloom et al., “Fertility, Female Labor Force Participation, and the Demographic Dividend," Journal of Economic Growth 14, no. 2 (2009): 79 - 10 
30. David E. Canning and Heather Schofield (2007)The Effect of Fertility on Female Labor Supply and Household Poverty in Indonesia (Boston: Harvard School of Public Health,2007)

31. Drago, R., Black, D., and Wooden, M. (2005). Female breadwinner families: Their existence,persistence and sources. Journal of Sociology 41(4): $343-362$. doi:10.1177/1440783305058465.

32. Goldin, Claudia, and Lawrence Katz. 2002. "The Power of the Pill: Oral Contraceptives

33. and Women's Career and Marriage Decisions." Journal of Political Economy 110, no. 4: 730-70.

34. Goldscheider, F., Bernhardt, E., and Brandén, M. (2013). Domestic gender equality and childbearing in Sweden. Demographic Research 29 (40): 1097-1126. doi:10. 4054/DemRes.2013.29.40.

35. Guldi, Melanie. 2008. "Fertility Effects of Abortion and Birth Control Pill Access for Minors." Demography 45,. 4: 817-27.

36. Hindin MJ(2000), Women's autonomy, women's status and fertility-related behavior in Zimbabwe, Population Research and Policy Review, 2000, 19(3):255-282. http://dx.doi.org/10.1023/A:1026590717779

37. Hoem Jan M. Neyer Gerda, Andersson Gunnar (2006) Educational attainment and ultimate fertility among Swedish women born in 1955-59 DemographicResearch Vol (14), pages 381-404 MaxPlanck-Gesellschaft

38. Kamal Mostafa (2012) Decline in Child Marriage and Changes in Its Effect

39. on Reproductive Outcomes in Bangladesh Health Popul Nutr 30(3):317-330.

40. ,

41. Kravdal, O., 2002. "Education and Fertility in sub-Saharan Africa: Individual and Community Effects." Demography. 39:2 pp 233-250

42. Lam, D. and S. Duryea, 1999. "Effects of Schooling on Fertility, Labour Supply and Investments in Children, with Evidence from Brazil." The Journal of Human Resources,Vol. 34, No.1, pp 160-192

43. Lerch Mathias (2013) Patriarchy and fertility in Albania Demographic Research, Vol.29, pp. 133-166

44. Lloyd. Cynthia B (2005). Schooling and Adolescent Reproductive Behavior in Developing Countries; World Bank. (2007). Moving Forward with Girls' Education in the World Bank:The Changing Context and What It Means for the Future

45. Luna K.C, Gemma Van Der Haar, \& Dorothea Hilhorst (2017) Changing Gender Role: Women's Livelihoods, Conflict and Post-conflict Security in Nepal Journal of Asian Security

46. and International Affairs 4(2) 175-195 2017 SAGE Publications India

47. Malhotra, Anju, Sidney Ruth Schuler, and Carol Boender. 2002. "Mea suring Women's Empowerment as a Variable in International Devel opment." Paper commissioned by the Gender and Development Group of the World Bank. Unpublished

48. Miller, Amalia R. 2009. "Motherhood Delay and the Human Capital of the Next Generation."American Economic Review 99, no. 2: $154-58$.

49. - 2013. "Marriage Timing, Motherhood Timing and Women's Wellbeing in Retirement."In Lifecycle Events and Their Consequences: Job Loss, Family Change, and Declines in Health, edited by Kenneth A. Couch, Mary C. Daly, and Julie Zissimopoulos. Stanford University Press

50. -2011. "The Effects of Motherhood Timing on Career Path." Journal of Population Economics 24, no. 3: 1071-1100

51. Nanfosso \& Zamo-Akono, 2010 Fertility, Health and Female Labour Force Participation in Urban Cameroon International Business Research Vol. 3, No. 2; April 2010 137-156

52. Nistha Sinha (2005), "Fertility, Child Work, and Schooling Consequences of Family Planning Programs: Evidence From an Experiment in Rural Bangladesh," Economic Development and Cultural Change 54, no. 1 (2005): 97-128

53. Psacharopoulos George \& Patrinos Harry Anthony. (2002) Returns to Investment in Education:A Further Update.

54. Rastogi S and Nguyen K, “Women's status and contraceptive use in Egypt”. [Unpublished]2005. Presented at the 2005 Annual Meeting of the Population Association of America,Philadelphia, Pennsylvania, March 31-April 2, 2005.24p.

55. Rogers, S.J. and D.D. DeBoer (2001) 'Changes in Wives' Income: Effects on Marital Happiness, Psychological Well-being, and the Risk of Divorce', Journal of Marriage and the Family 63(2): 458-471.

56. Drago R, Black D \& Wooden M (2004) Female Breadwinner Families: Their Existence, Persistence and Sources. The Institute for the Study of Labor (IZA) Discussion Paper No. 1308 http://ssrn.com/abstract=592323

57. Shapiro D (2008) Fertility Transition in sub-Saharan Africa: falling and stalling, African Population Studies, 2008, 22(2):3-23.

58. Shareen Joshi 2012 Reproductive Health And Economic Development: What Connections Should We Focus On? PRB Research Brief

59. Stern, S. (1989). Measuring the effect of disability on labour force participation. The Journal of Human Resources, 24(3), $361-395$.

60. Tortarolo, D. (2014). “Female Labor Supply and Fertility. Causal Evidence for Latina

61. America" CEDLAS Working Paper No. 166.

62. Vitali Agnese and Arpino Bruno (2016) Who brings home the bacon? The influence of context on partners' contributions to the household income Demographic Research, Vol.35 (JULY - DECEMBER 2016), pp. 1213-1244 Published by: Max-Planck-Gesellschaft zur Foerderung der

63. Wissenschaften Stable URL: https://www.jstor.org/stable/26332109 Accessed: 20-06-2019 09:39 UTC

64. Woldemicael G, (2009) Women's autonomy and reproductive preferences in Eritrea, Journal of Biosocial Science, 2009, 41(2):161-181. http://dx.doi.org/10.1017/S0021932008003040

65. Yang Juhua (2017) Gendered division of domestic work and willingness to have more children in China:Demographic Research, (37) 1949-1974 
Figures

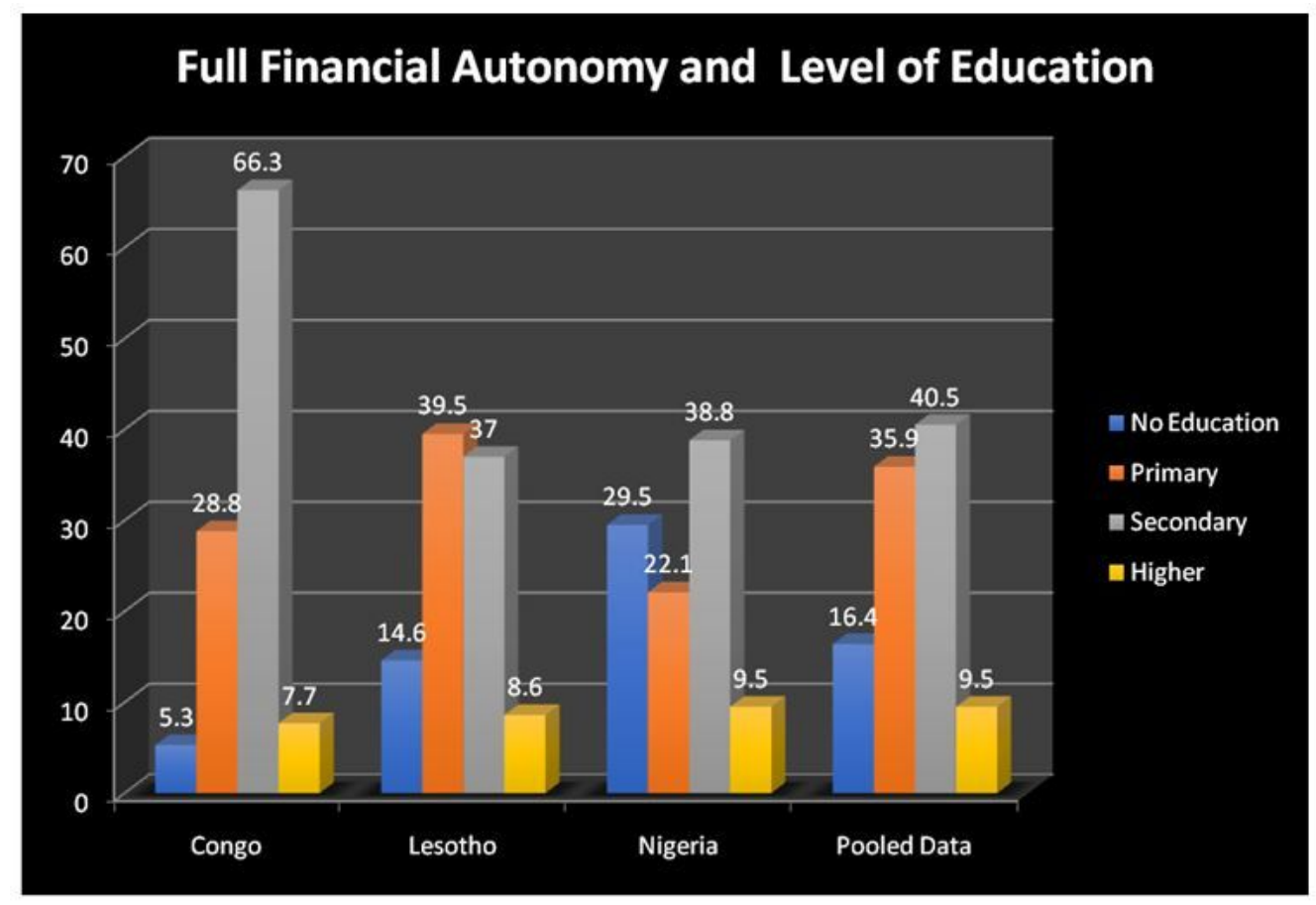

Figure 1

Source : Compiled by the author from NDHS data

Full Financial Autonomy and Age At First Cohabitation

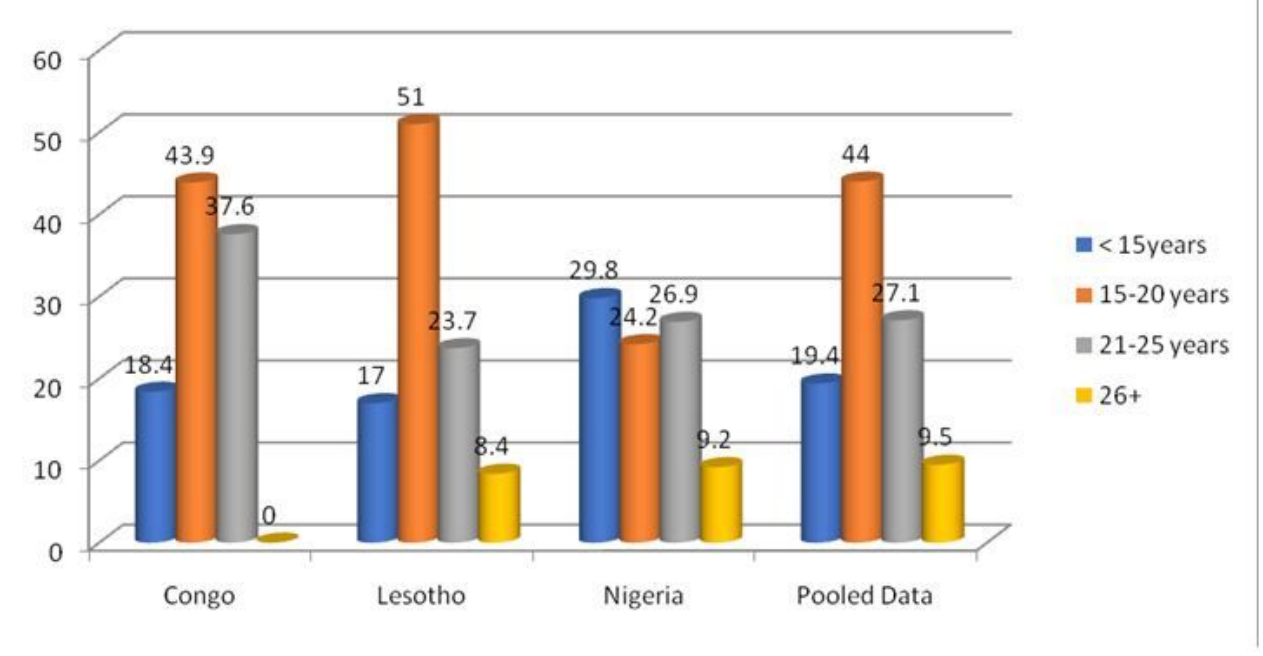

Figure 2

Source: Compiled by the author from NDHS data 